was stable to physicochemical denaturing agents. Out of this arose our collaboration in chemical embryology, studying what we used to like to call the 'morphogenetic hormones'-a conception still necessary today, although remarkably little progress has been made in the identification of these intermediate products of the genes.

Wad made a splendid collaborator. In intellectual grasp and analytical penetration I always felt he was gifted far beyond me. The great thing about him was that he was a man with whom it was impossible to quarrel. When one knew him only a little in those young days one might at first think him unduly reserved, even cold, with no room for the passionate at all; but this was quite a misconception, because throughout his life he enjoyed many deep friendships and attachments with people of very varying ages. At the same time he was singularly 'unflappable', a quality that stood him in good stead when in the field for geology or exploration. Always politically progressive but entirely without fanaticism, he would do everything he could to help younger people, and those who were refugees from their own lands.

Another aspect which I appreciated so much in him was his understanding of forms of experience other than that of the natural sciences, notwithstanding his fundamental and all-pervading deep rationality. In his case it was philosophy and the nature of aesthetic experience to which he was largely drawn, which might account in part for his marrying a brilliant architect; in my case it was always religion and theology, but we never had any disagree- ments on such matters. Besides, we came together very closely on the ground of ethics, because we were both entirely convinced that the only ultimate salvation of humanity would lie in the control of the discoveries of the natural sciences by an cthic, a morality; the latter would have to be an entirely new one, congruent with the vast increases in human knowledge and the frightening powers over Nature which humanity was acquiring and would acquire. There has been no-one in my life whom I have liked and admired more, and I can only hope that his writings and his philosophical outlook will still influence younger people for many years to come.

\section{Joseph Needham}

John Wilfred Linnett, FRS, Master of Sidney Sussex College, Cambridge, and a noted theoretical chemist, died on November 7 , at the age of 62 .

JACK LINNETT was born on August 3, 1913, and educated at King Henry VIII School, Coventry, and St John's College, Oxford. After holding a Research Fellowship at Balliol he was made a Fellow of Queen's College, Oxford, in 1945. He was for twenty years first a Demonstrator then a Reader in the Inorganic Chemical Laboratory in Oxford, and was appointed Professor of Physical Chemistry at Cambridge in 1965. After a period as a Professorial Fellow at Emmanuel he was elected Master of Sidney Sussex College in 1970. He served as Vice-Chancellor at Cambridge from 1973-75, and had relinquished this arduous post only five weeks before his death. He was president of the Faraday Division of the Chemical Society from 1971-73, and was to have become President of the Chemical Society in 1976 . He had been a visiting professor at the Universities of Wisconsin, California, Cornell and Minnesota, and had strong ties with Malaysia and Singapore in his capacity as an External Examiner. His two books on valence theory are known to all undergraduates, and his 260 published papers covered such a variety of chemical topics that they stamp him as unique: infrared spectroscopy, combustion and flames, force constants, kinetics, catalysis, surfaces, wave mechanics. There are few aspects of physical or theoretical chemistry on which he has not left his mark. He was elected a Fellow of the Royal Society in 1955; had served the city of Oxford as a JP; and was an Honorary Fellow of Queen's and St John's Colleges, Oxford. In recent years he had become increasingly interested in the teaching of chemistry as an educational process in its own right, and devoted much time to communicating his thoughts on this topic to others. In spite of the enormous demands on his time, he was always accessible to undergraduates, research students, colleagues, staff and friends, and was willing to give advice and lend a hand whenever and wherever it was required. $\mathrm{He}$ died very abruptly on 7 November 1975, typically between giving a PhD oral and addressing the Royal Society, at the very height of a formidable career. It is difficult to assess how many people will be needed to fill the gap that he has left.

P. J. Wheatley

\title{
announcements
}

\section{Awards}

The French Academy of Science has awarded its main annual prize jointly to S. Brenner and S. Benzer for their achievements in the field of molecular genetics.

G. Barsky and B. Ephrussi have been awarded the Paul Ehrlich Award for their pioneering work on cell fusion.

The 1975 Albert Lasker Awards are as follows : The Clinical Medical Research Award to G. N. Hounsfield and W. Oldendorf; A Basic Medical Research Award to R. C. L. Guillemin and A. V. Schally; Another Basic Medical Research Award to F. Dixon and H. G. Kunkel; The Special Award to K. H. Beyer, J. M. Sprague, J. E. Baer and
F. C. Novello; The Public Service Award goes to J. Stein.

\section{Appointment}

K. P. Duncan has been appointed a member of the Medical Research Council.

\section{Reports and publications}

\section{Other countries}

Publications du Centre National pour l'Exploitation des Oceans (CNEXO). Série: Rapports Scientifiques et Techniques, No. 21: Isolement in situ d'Eau de MerNaturelie dans des Enceintes de Grand Volume: Application a l'Étude d'Une Eutrophisation Intérêt e Prospective. Par Brigette R. Berland, Daniel J. Bonin et Serge Y. Maestrini. Pp. 18. (Paris: CNEXO, 1975.) Smithsonian Contributions to Zoology. No. 192 : Review of Ochsenheimeriidae and the Introduction of the Cereal Stem Moth Orhsenheimeria vacculella into the United States (Lepidoptera: Tineoidea). By Donald R. Davis. Pp. iii $\nmid$ 20. No. 193; The Principal Larrea Bees of the Southwestern United State (Hymenoptera: Apoidea). By Paul D. Hurd, Jr., and
Smithsonian Institution Press, 1975. For sale by US Government Printing Office.) CERN - European Organization for Nuclear Research. CERN 75-11: Polarized Particles for Accelerator Physicists. By J. S. Bell. Pp. vil + 37 . Geneva: CERN, 1975.)

United States of the Interior: Geological Survey. Professional Paper 898: Slump Blocks in the Atlantic Pp. iii +24 . (Washington, DC: Government Printing Office, 1974.) 95 cents.

Smithsonian Contributions to Zoology, No 198 Ctenuchid Moths of Ceramidia Butler, Ceramidiodes Hampson, and the Caca Species Group of Antichloris Hubner. By William D. Field. Pp. iii + 45. (Washingon. DC: Smithsonian Institution Press, 1975. For sale by US Government Printing Office.) International Institute for Applied Systems Analysis. Annual Report --IIASA '74. Pp. xiv + 42. (Laxenburg. Austria: IIASA; London: The Royal Society, 1975. Coastal Water Research Project-Annual Report for the year ended 30th June 1975. Pp. v +211 (El Segundo, California: Southern California Coasta Water Research Project, 1500 East Imperial Highway, 1975 United States Department of the Interior: Geological Survey. Professional Paper 837: The Logic of Geological Maps, With Reference to Their Interpretation and Use for Engineering Purposes, By David J Varnes. Pp. iii + 48. \$3.50. Professional Paper 856: Structure and Origin of the Koae Fault System, Kilauea Volcano, Hawail, By Wendell A. Duffield. Pp. v + 12 + plate 1. (Washington, DC. Government 